\title{
Anterior Cervical Discectomy and Fusion (ACDF): Comparison Between Zero Profile Implants and Anterior Cervical Plate and Spacer
}

Marjan Alimi ${ }^{1}$, Innocent Njoku ${ }^{1}$, Christoph P. Hofstetter ${ }^{1}$, Apostolos J. Tsiouris ${ }^{2}$, Kartik Kesavabhotla $^{1}$, John Boockvar ${ }^{3}$, Rodrigo Navarro-Ramirez ${ }^{1}$, Roger Härtl ${ }^{4}$

1. Department of Neurosurgery, Weill Cornell Medical College, New York Presbyterian Hospital, New York 2. Radiology, Division of Neuroradiology, Weill Cornell Medical College, New York Presbyterian Hospital, New York 3. Department of Neurosurgery, Lenox Hill Hospital, New York 4. Department of Neurosurgery, NewYork-Presbyterian/Weill Cornell Medical Center

$\square$ Corresponding author: Rodrigo Navarro-Ramirez, neuronavarro@gmail.com Disclosures can be found in Additional Information at the end of the article

\section{Abstract}

Introduction: Interposition grafts combined with anterior plating currently remain the gold standard for anterior cervical discectomy and fusion. The use of anterior plates increases fusion rates but may be associated with higher rates of postoperative dysphagia. The aim of the current study was to determine the clinical and radiological outcomes following anterior cervical discectomy and fusion (ACDF) using zero-profile anchored spacers versus standard interposition grafts with anterior plating.

Methods: This was a retrospective case series. A total of 53 male and 51 female consecutive patients (164 total operated levels) who underwent ACDF between 2007 and 2011 were included. The mean clinical follow-up was $15.7 \pm 1.2$ (SEM) months for patients with zeroprofile implants and $14.8 \pm 2.1$ months for patients with conventional ACDF with anterior plating. Patient demographics, operative details, clinical outcomes, complications, and radiographic imaging were reviewed. Dysphagia was determined using the Bazaz criteria.

Results: Clinical outcome scores improved in both groups as measured by the modified Japanese Orthopedic Association and Nurick scores. Zero-profile constructs gave rise to significantly less prevertebral soft tissue swelling compared to constructs with anterior plates postoperatively $(15.74 \pm 0.52$ as compared to $20.48 \pm 0.85 \mathrm{~mm}, \mathrm{p}<0.001)$ and at the latest follow-up $(10.88 \pm 0.39 \mathrm{~mm}$ vs. $13.72 \pm 0.67 \mathrm{~mm}, \mathrm{p}<0.001)$. There was a significant difference in the incidence of dysphagia at the latest follow-up (1.5\% vs. $20 \%, \mathrm{p}=0.001$, zero-profile vs.

Received 10/07/2015 Review began 10/08/2015 Review ended 04/11/2016 Published 04/17/2016

(C) Copyright 2016

Alimi et al. This is an open access article distributed under the terms of the Creative Commons Attribution License CC-BY 3.0., which permits unrestricted use, distribution, and reproduction in any medium, provided the original author and source are credited. anterior plate, respectively).

Conclusion: Zero-profile implants lead to functional outcomes similar to standard anterior plate constructs. Avoiding the use of an anterior locking plate may decrease the risk of persistent postoperative dysphagia.

Categories: Neurosurgery, Orthopedics

Keywords: anterior cervical discectomy and fusion, acdf, anterior plate, clinical outcome, dysphagia, radiographic, zero-profile 


\section{Introduction}

Anterior cervical discectomy and fusion (ACDF) is a well-established technique for treatment of cervical myelopathy and radiculopathy. The technique aims at establishing neural decompression and providing segmental stability at the symptomatic cervical level [1]. Since its initial description nearly 50 years ago, the technique has undergone extensive modifications [23]. The current standard method combines an anterior locking plate with either a synthetic, allograft, or metallic interposition graft [3-9]. While the addition of an anterior plate enhances the biomechanical stability of the construct and leads to a higher fusion rate, it has also been associated with prevertebral soft tissue injury and dysphagia [10-14].

Several factors are assumed to have a role in the increased rates of dysphagia following ACDF with anterior plating, such as retraction, direct impingement of the esophagus, and irritation of surrounding soft tissue [15-18].

A zero-profile plate may exert less of a mass effect on the esophagus. It has been approved by the FDA for anterior intervertebral screw fixation of the cervical spine at levels C2-T1. Recently, several studies have demonstrated the utility of a zero-profile integrated plate and spacer and documented its clinical as well as radiographic outcome measures [19-20]. ACDF with plating has been found by many studies to be associated with a high rate of postoperative dysphagia, up to a clinical incidence of $51 \%$ in some studies [11-12, 16, 21]. A previous study showed that zero-profile anchored spacers can lead to similar clinical and radiographical outcomes as ACDF with plating, yet carry a lower risk for persistent dysphagia [14].

In the current study, we compared zero-profile devices to conventional ACDF with an anterior plate, focusing on the rate of persistent dysphagia and prevertebral soft-tissue swelling.

\section{Materials And Methods}

\section{Patient population}

We conducted a retrospective analysis of a prospectively collected database, assessing patients who underwent an ACDF between October 2007 and October 2011 at a single center.

A total of 104 patients with 164 operated levels were included. Our current series encompasses one-third of our patients receiving the Zero-P implant (Synthes ${ }^{\circledR}$, West Chester, PA), another third receiving the ROI-C implant (LDR-Spine, Austin, TX), and the final third receiving a DePuy carbon-fiber cage (BENGAL ${ }^{\circledR}$, DePuy Synthes) combined with an anterior plate (SKYLINE ${ }^{\circledR}$, DePuy Synthes) (Table 1). 


\section{Cureus}

\begin{tabular}{|c|c|c|c|}
\hline \multirow[b]{2}{*}{ Product } & \multicolumn{2}{|l|}{ Zero-Profile Device } & \multirow{2}{*}{$\begin{array}{l}\text { Anterior Plate } \\
\text { Skyline }\end{array}$} \\
\hline & Zero-P & ROI-C (LDR) & \\
\hline Material & PEEK with integrated titanium plate & PEEK & Titanium plate \\
\hline $\begin{array}{l}\text { Depth } \times \text { Width } \\
(\mathrm{mm})\end{array}$ & $13.5 \times 17.5$ & $\begin{array}{l}12 \times 14 ; 12 \times 15.5 ; 14 \times 14 ; 14 \\
\times 15.5 ; 14 \times 17\end{array}$ & N/A \\
\hline Height (mm) & $5,6,7,8,9,10,11,12$ & $\begin{array}{l}4.5,5,5.1,5.5,6,6.5,7,7.5,8 \\
8.5\end{array}$ & $12-102$ \\
\hline $\begin{array}{l}\text { Anterior } \\
\text { Thickness } \\
(\mathrm{mm})\end{array}$ & 0 & 0 & 2.5 \\
\hline Sagittal Profile & Convex, parallel, lordotic & Convex & Lordotic \\
\hline $\begin{array}{l}\text { Anchoring } \\
\text { Device }\end{array}$ & $\begin{array}{l}4 \text { screw construct, self-tapping, } 3.0 \\
\text { mm anchoring device }\end{array}$ & $\begin{array}{l}2 \text { screw construct, self-drilling, } \\
3.5 \mathrm{~mm} \text { diameter }\end{array}$ & $\begin{array}{l}\text { 4-12 screw construct, self- } \\
\text { tapping, self-drilling }\end{array}$ \\
\hline $\begin{array}{l}\text { Screw Length } \\
(\mathrm{mm})\end{array}$ & $12,14,16$ & $8,10,12,24$ & $\begin{array}{l}10,12,13,14,15,16,17,18 \\
20,22,24,26\end{array}$ \\
\hline $\begin{array}{l}\text { Screw } \\
\text { Angulation }\end{array}$ & Fixed only & Parallel insertion & $5^{\circ}-20^{\circ}$ angulation \\
\hline $\begin{array}{l}\text { Blocking } \\
\text { Mechanism }\end{array}$ & Screw threads into the plate & Self-locking clips & Screw-threaded interplate \\
\hline
\end{tabular}

TABLE 1: Implant Characteristics and Versatility

The first and second third were grouped together as patients receiving zero-profile implants and were compared to the final third, who received anterior plates.

Although patients were not randomized, statistical tests were performed to assess whether the demographic and/or peri-operative characteristics of the patients were significantly different between the two groups. All patients had symptomatic degenerative cervical disc disease or disc herniation between the levels of C3/4 to C7/T1. Epidemiological data, the location of pathology, levels of fixation, surgery time, estimated blood loss, the length of hospital stay, complications, and follow-up data were collected. Institutional review board approval was obtained for this project.

\section{Surgical technique}

In this procedure, patients were intubated via general endotracheal techniques. We utilized a Smith-Robinson approach to reach the diseased level(s) [3]. Patients were positioned supine on the operating table. A horizontal curvilinear incision was made from midline to the anterior aspect of the sternocleidomastoid muscle. Soft tissue was dissected and the carotid artery was mobilized laterally while the trachea and esophagus were mobilized medially. Once the prevertebral space was accessed, the medial longus colli muscle was dissected off the vertebral bodies. Distraction pins were placed under fluoroscopic guidance and osteophytes were 
removed with a high-speed drill under the operating room microscope. Discectomies were performed using straight curettes and pituitary rongeurs. The posterior longitudinal ligament was resected using Kerrison rongeurs.

The wound was irrigated and closed in standard fashion. Patients received standard postoperative care and appropriate analgesic medication in addition to gastric ulcer and deep venous thrombosis prophylaxis. Patients were placed in a collar postoperatively only if they were smokers.

\section{Clinical evaluation}

Clinical outcome scores were collected preoperatively, immediately postoperatively, and at the latest follow-up. Neurological impairment was assessed by the Nurick [22] and modified Japanese Orthopedic Association scores (JOA) [23-24]. Dysphagia was recorded and graded according to the Bazaz scoring system [12]. A numerical score ranging from 0 (no episodes of swallowing difficulty) to 3 (severe difficulty with the majority of the food) was noted for each patient. Intraoperative and postoperative complications were recorded.

\section{Radiographic evaluation}

Anteroposterior (AP) and lateral cervical radiographs were used to evaluate the cervical prevertebral soft tissue thickness, as well as hardware failure and/or instability immediately postoperatively and at the latest follow-up. The prevertebral soft tissue thickness was measured in the mid-portion of the fusion construct. Measurements were recorded to the nearest half millimeter. The occurrence of bony fusion was assessed on the AP and lateral cervical spine $\mathrm{x}$ rays six months following surgery. In patients with an available CT scan, the fusion was assessed using the latter imaging. Trabecular bridging across the bone-graft interface and absence of radiolucent gaps between the graft and vertebral endplate were the radiographic criteria used to assess fusion.

\section{Statistical analysis}

Continuous variables are shown either as mean \pm standard error from means or as median (min; max). Percentages were calculated for categorical variables. Differences between the two compared groups in the categorical variables were assessed using a Chi-square test. Differences between continuous variables were tested using a Student's T-test. All analyses were performed using appropriate statistical software (SPSS Version 18.0.0.1, SPSS Inc., Chicago, IL).

\section{Results}

\section{Demographic and perioperative data}

One hundred and four patients (34 Zero-P, 35 ROI-C, and 35 anterior plates) were operated on with a combined total of 164 levels (110 levels with a zero-profile device and 54 levels with an anterior plate) (Figure 1). 


\section{Cureus}

Number of fusion segments

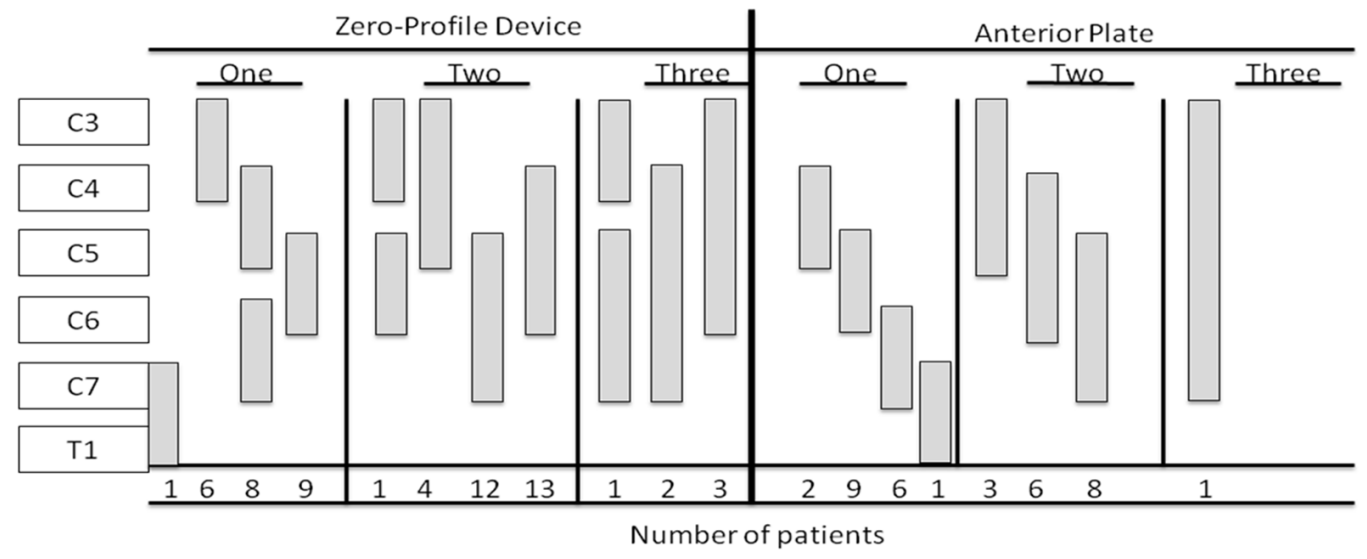

FIGURE 1: Illustration of Fused Vertebral Segments as a Function of the Number of Operated Patients

Our cohort consisted of 53 male and 51 female patients. The average age of the cohort was 55.9 \pm 1 .20. Patients who received a zero-profile device were significantly older than patients who received a standard construct with an anterior plate $(58.2 \pm 1.45$ years vs. $51.5 \pm 1.95$, respectively, $\mathrm{P}=0.007$ ). The gender distribution, mean $\mathrm{BMI}$, and the severity of the preoperative neurological impairment were similar between the two groups. Also, there were no statistically significant differences between the two groups in the number of operated levels, estimated blood loss, and/or duration of the follow-up (Tables 2-3).

\section{Patient Characteristics}

Age at surgery (years) ${ }^{1}$

Gender

$\operatorname{BMI}\left(\mathrm{kg} / \mathrm{m}^{2}\right)^{1}$

\section{All Cases (104 pts)}

$55.9 \pm 1.20$

Male

$53(51 \%)$

Female $51(49 \%)$

$28.1 \pm 0.66$
ROI-C \& Zero-P (69 pts)

$58.2 \pm 1.45$

$35(50.7 \%)$

$34(49.3 \%)$

$28.0 \pm 0.76$
Anterior Plate (35 pts)

$51.5 \pm 1.95$

$18(51.4 \%)$

$17(48.6 \%)$

$28.2 \pm 1.36$
$0.946^{* *}$

\section{$P$ value}

$0.007^{*}$

$0.924^{*}$

\section{TABLE 2: Patient Characteristics}

${ }^{*} P$ values $<0.05$ are considered to be statistically significant

${ }^{* \star}$ Denotes the difference in gender distribution (male - female)

${ }^{1}$ Mean \pm SE 


\section{Cureus}

\begin{tabular}{|c|c|c|c|c|c|}
\hline Surgical Details & & $\begin{array}{l}\text { All Cases (104 pts, } \\
164 \text { Levels) }\end{array}$ & $\begin{array}{l}\text { ROI-C \& Zero-P (69 pts, } \\
110 \text { Levels) }\end{array}$ & $\begin{array}{l}\text { Anterior Plate (35 pts, } \\
54 \text { Levels) }\end{array}$ & $\begin{array}{l}P \\
\text { value }\end{array}$ \\
\hline \multirow[t]{3}{*}{$\begin{array}{l}\text { Number of levels / } \\
\text { patient }\end{array}$} & $\begin{array}{l}1 \\
\text { level }\end{array}$ & $49(4 / .1 \%)$ & $32(46.4 \%)$ & $17(48.6 \%)$ & \\
\hline & $\begin{array}{l}2 \\
\text { levels }\end{array}$ & $50(48.1 \%)$ & $33(47.8 \%)$ & $17(48.6 \%)$ & 0.935 \\
\hline & $\begin{array}{l}3 \\
\text { levels }\end{array}$ & $5(4.8 \%)$ & $4(5.8 \%)$ & $1(2.9 \%)$ & \\
\hline \multirow[t]{5}{*}{ Level of surgery } & $\mathrm{C} 3 / \mathrm{C} 4$ & $19(11.6 \%)$ & $15(13.6 \%)$ & $4(7.4 \%)$ & \\
\hline & C4/C5 & $42(25.6 \%)$ & $30(27.2 \%)$ & $12(22.3 \%)$ & \\
\hline & C5/C6 & $64(39.0 \%)$ & $41(37.2 \%)$ & $23(42.6 \%)$ & \\
\hline & C6/C7 & $36(22.0 \%)$ & $22(20.0 \%)$ & $14(25.9 \%)$ & \\
\hline & C7/T1 & $3(1.8 \%)$ & $2(1.8 \%)$ & $1(1.8 \%)$ & \\
\hline $\begin{array}{l}\text { Estimated Blood } \\
\text { Loss }(E B L)^{1}\end{array}$ & & $50(0 ; 600)$ & $50(0 ; 600)$ & $50(20 ; 500)$ & 0.109 \\
\hline Follow-up duration ${ }^{2}$ & & $15.4 \pm 1.08$ & $15.7 \pm 1.23$ & $14.8 \pm 2.13$ & 0.688 \\
\hline
\end{tabular}

\section{TABLE 3: Surgical Details and Operated Levels}

${ }^{*} \mathrm{P}$ values $<0.05$ are considered to be statistically significant

${ }^{1}$ Estimated Blood Loss (EBL); Median (min; max)

2 Mean \pm SE

\section{Clinical results}

Clinical outcomes were assessed using the modified JOA and the Nurick scores (Table 4). 


\section{Cureus}

Clinical Outcome (In Each Group) ${ }^{1}$

\section{All cases}

Nurick

JOA

ROI-C \& Zero-P (69 patients, 110 levels)
$1.19 \pm 0.14$

$13.54 \pm 0.24$
Latest Follow-up

$P$ value
$0.96 \pm 0.11$

$13.62 \pm 0.17$
$0.57 \pm 0.07$

$15.51 \pm 0.15$
$<0.001^{*}$

$<0.001^{*}$
Nurick

JOA

Anterior Plate (35 patients, 54 levels)

Nurick

JOA
$0.51 \pm 0.12$

$13.77 \pm 0.18$
$0.65 \pm 0.09$

$<0.001^{*}$

$15.57 \pm 0.20$

$<0.001^{*}$

\section{TABLE 4: Clinical Outcome in All Patients and in Each Group}

${ }^{*} P$ values $<0.05$ are considered to be statistically significant

${ }^{1}$ Mean \pm SE

Patients who underwent implantation of the zero-profile device had functional outcomes comparable to the patients who received conventional constructs with anterior plating (Table $5)$. 


\section{Cureus}

\begin{tabular}{lllll|}
$\begin{array}{l}\text { Clinical Outcome (Comparison } \\
\text { Between Groups) }\end{array}$ & $\begin{array}{l}\text { All Cases } \\
(\mathbf{1 0 4} \mathbf{~ p t s )}\end{array}$ & $\begin{array}{l}\text { ROI-C \& Zero-P } \\
(\mathbf{6 9} \mathbf{~ p t s})\end{array}$ & $\begin{array}{l}\text { Anterior Plate } \\
(\mathbf{3 5} \mathbf{~ p t s})\end{array}$ & $\begin{array}{l}\text { P value (Intergroup } \\
\text { Difference) }\end{array}$ \\
\hline Preoperative Nurick & $0.96 \pm 0.11$ & $1.19 \pm 0.14$ & $0.51 \pm 0.12$ & 0.002 * \\
Last Follow-up Nurick & $0.57 \pm 0.07$ & $0.65 \pm 0.09$ & $0.43 \pm 0.10$ & 0.147 \\
Nurick Improvement & $0.38 \pm 0.09$ & $0.53 \pm 0.13$ & $0.09 \pm 0.04$ & 0.023 * \\
Preoperative JOA & $13.62 \pm 0.17$ & $13.54 \pm 0.24$ & $13.77 \pm 0.18$ & 0.540 \\
Last Follow-up JOA & $15.51 \pm 0.15$ & $15.57 \pm 0.20$ & $15.40 \pm 0.23$ & 0.605 \\
JOA Improvement & $1.88 \pm 0.14$ & $2.00 \pm 0.19$ & $1.63 \pm 0.21$ & 0.238
\end{tabular}

\section{TABLE 5: Comparison of the Clinical Outcome Between Groups}

${ }^{*} \mathrm{P}$ values $<0.05$ are considered to be statistically significant

${ }^{1}$ Mean $\pm \mathrm{SE}$

Dysphagia improved significantly in all patients from the postoperative time to the latest follow-up; this improvement could also be observed separately in each group (Table 6).

Dysphagia (In Each Group) ${ }^{1}$

\section{All cases}

Dysphagia score

ROI-C \& Zero-P (69 patients, 110 levels)

Dysphagia score

$0.85 \pm 0.12$

$0.10 \pm 0.04$

$<0.001^{*}$

Anterior Plate (35 patients, 54 levels)

Dysphagia score

$0.40 \pm 0.08$

$0.20 \pm 0.06$

$<0.006$ *

\section{TABLE 6: Dysphagia in All Patients and in Each Group}

${ }^{*} P$ values $<0.05$ are considered to be statistically significant

${ }^{1}$ Mean \pm SE

Although the average immediate postoperative dysphagia score was higher in the zero-profile group compared to the anterior plate group ( $0.85 \pm 0.12$ vs. $0.40 \pm 0.08$, respectively; $\mathrm{p}=0.018$ ), the extent of improvement at the latest follow-up time was significantly higher in zero-profile 


\section{Cureus}

group as well, compared to the anterior plate group $(0.75 \pm 0.11$ vs. $0.20 \pm 0.69$, respectively; $\mathrm{p}=0.002$ ). Correspondingly, the dysphagia score at the latest follow-up was not significantly different between the two groups (Table 7).

\begin{tabular}{|c|c|c|c|c|}
\hline $\begin{array}{l}\text { Dysphagia (Comparison } \\
\text { Between Groups) }\end{array}$ & $\begin{array}{l}\text { All Cases } \\
\text { (104 pts) }\end{array}$ & $\begin{array}{l}\text { ROI-C \& Zero-P } \\
\text { (69 pts) }\end{array}$ & $\begin{array}{l}\text { Anterior Plate } \\
\text { (35 pts) }\end{array}$ & $\begin{array}{l}\text { P value (Intergroup } \\
\text { Difference) }\end{array}$ \\
\hline $\begin{array}{l}\text { Immediate Postoperative } \\
\text { Dysphagia Score }{ }^{1}\end{array}$ & $0.70 \pm 0.09$ & $0.85 \pm 0.12$ & $0.40 \pm 0.08$ & $0.018^{*}$ \\
\hline $\begin{array}{l}\text { Latest Follow-up Dysphagia Score } \\
1\end{array}$ & $0.14 \pm 0.03$ & $0.10 \pm 0.04$ & $0.20 \pm 0.06$ & 0.211 \\
\hline Dysphagia Score Improvement ${ }^{1}$ & $0.56 \pm 0.08$ & $0.75 \pm 0.11$ & $0.20 \pm 0.69$ & 0.002 * \\
\hline $\begin{array}{l}\text { Immediate Postoperative } \\
\text { Dysphagia Incidence }\end{array}$ & $33(31.7 \%)$ & $19(27.9 \%)$ & $14(40.0 \%)$ & 0.214 \\
\hline $\begin{array}{l}\text { Latest Follow-up Dysphagia } \\
\text { Incidence }\end{array}$ & $8(7.7 \%)$ & $1(1.5 \%)$ & $7(20.0 \%)$ & $0.001^{*}$ \\
\hline Dysphagia Incidence Improvement & $25(24 \%)$ & $18(26.1 \%)$ & $7(20.0 \%)$ & 0.468 \\
\hline
\end{tabular}

\section{TABLE 7: Comparison of Dysphagia Between Groups}

${ }^{*} P$ values $<0.05$ are considered to be statistically significant

${ }^{1}$ Mean \pm SE

In addition to the Nurick score, patients were assessed for the presence or absence of dysphagia. In the postoperative period, $27.9 \%$ of patients with the zero-profile implant experienced transient dysphagia as compared to $40 \%$ of the patients in the anterior plate group. However, at the latest follow-up, $1.5 \%$ of patients in the zero-profile group continued experiencing dysphagia, compared to $20 \%$ in the anterior plate group $(p=0.001)$.

\section{Radiographic results}

Prevertebral soft tissue thickness significantly decreased from the postoperative time to the latest follow-up in all patients as well as in each group separately (Table 8). 


\section{Cureus}

Prevertebral Soft Tissue Thickness (In Each Group) ${ }^{1}$

All cases

Tissue thickness

ROI-C \& Zero-P (69 patients, 110 levels)

Tissue thickness

Anterior Plate (35 patients, 54 levels)

Tissue thickness

\section{Immediate Postoperative}

Latest Follow-up

P value

$17.30 \pm 0.50$

$11.81 \pm 0.36$

$<0.001^{*}$

\section{TABLE 8: Prevertebral Soft Tissue Thickness in All Patients and in Each Group}

${ }^{*} \mathrm{P}$ values $<0.05$ are considered to be statistically significant

${ }^{1}$ Mean \pm SE

Nonetheless, the postoperative prevertebral soft tissue thickness was significantly lower in patients with the zero-profile implants compared to those with the anterior plate $(15.74 \pm 0.52$ mm vs. $20.48 \pm 0.85 \mathrm{~mm}$, respectively; $\mathrm{p}<0.001$ ) (Table 9).

\begin{tabular}{|c|c|c|c|c|}
\hline $\begin{array}{l}\text { Prevertebral Soft Tissue } \\
\text { Thickness (Comparison Between Groups) }{ }^{1}\end{array}$ & $\begin{array}{l}\text { All Cases } \\
\text { (104 pts) }\end{array}$ & $\begin{array}{l}\text { ROI-C \& Zero- } \\
\text { P (69 pts) }\end{array}$ & $\begin{array}{l}\text { Anterior Plate } \\
\text { (35 pts) }\end{array}$ & $\begin{array}{l}\text { P value (Intergroup } \\
\text { Difference) }\end{array}$ \\
\hline Immediate postoperative tissue thickness & $\begin{array}{l}17.30 \pm \\
0.50\end{array}$ & $15.74 \pm 0.52$ & $20.48 \pm 0.85$ & $<0.0001$ * \\
\hline Latest follow-up tissue thickness & $\begin{array}{l}11.81 \pm \\
0.36\end{array}$ & $10.88 \pm 0.39$ & $13.72 \pm 0.67$ & $<0.0001$ * \\
\hline Tissue thickness reduction & $5.41 \pm 0.42$ & $4.90 \pm 0.47$ & $6.52 \pm 0.84$ & 0.073 \\
\hline
\end{tabular}

\section{TABLE 9: Comparison of Prevertebral Soft Tissue Thickness Between Groups}

${ }^{*} P$ values $<0.05$ are considered to be statistically significant

${ }^{1}$ Mean \pm SE

At the latest follow-up, the prevertebral soft tissue thickness remained significantly lower in the zero-profile group as compared to the anterior plate group $(10.88 \pm 0.39 \mathrm{~mm}$ vs. $13.72 \pm 0.67$ $\mathrm{mm}, \mathrm{p}<0.001)$. The radiographic fusion rates for patients undergoing an ACDF with the zeroprofile implant and with anterior plate were $92.1 \%$ and $96 \%$, respectively. The difference in the fusion rate between the two groups was not statistically significant $(\mathrm{p}=0.501)$. In addition, there were no statistically significant differences in the fusion rates for single level, two level, and 
three level surgeries.

\section{Discussion}

ACDF constitutes a well-established treatment modality for cervical myelopathy and radiculopathy. In our current study, we demonstrated that a zero-profile device allows for similar clinical and radiographic outcomes compared to a conventional construct with an anterior plate, while reducing the rate of postoperative dysphagia.

Overall, it seems that dysphagia is still a major concern for this procedure $[11-12,16$, 21]. Hofstetter, et al. showed that zero-profile anchored spacers can result in a lower dysphagic incidence when compared to historical data on anterior plate surgery [14]. Similarly, our study showed lower rates of postoperative dysphagia with zero profile devices, regardless of the manufacturing company, compared to an anterior locking plate. The chronic dysphagia rate in our cohort of patients utilizing a zero-profile device was $1.5 \%$, which was lower than the rates reported in the literature for studies utilizing traditional anterior plate and spacer constructs [11-12, 16, 21, 25-26].

\section{Dysphagia}

Chronic dysphagia is a well-known complication following ACDF with an anterior plate [12, 1617, 27]. The pathophysiology of dysphagia after ACDF is not well understood but it appears to be caused by multiple factors, such as retraction during implantation, irritation of tissue, and mass effect on the esophagus [17, 28].

Several factors have been proposed to contribute to increased rates of dysphagia following ACDF with anterior plating, among which are additional retractions required for plate implantation, direct impingement of the esophagus by the plate as well as irritation of surrounding soft tissue [15-16].

One plausible explanation underlying the increased risk of dysphagia with anterior plating may be due to additional esophageal retraction necessary for placement and implantation of the anterior plate. Pressure applied by the retractor blade onto the pharynx/esophagus can cause local ischemic damage inside the esophageal wall. Additionally, it is conceivable to attribute such complications to soft tissue edema, postoperative hematoma, or esophageal irritation [17]. Direct esophageal contact between the device and soft tissue can also add to irritation leading to soft tissue edema of the esophageal wall [18].

It has been suggested that plate design may play a substantial role in the development of chronic dysphagia. The thickness of the cervical plate and its position directly posterior to the esophagus may contribute to this complication by causing soft tissue irritation [12, 27, 29]. A study done by Mobbs, et al. showed significantly higher rates of dysphagia in patients who received anterior plates as compared to constructs without anterior plating [29]. In a two-year prospective longitudinal follow-up study with 156 patients, Lee, et al. found that utilization of smaller and smoother profile plates was associated with decreased incidence of dysphagia compared to the implantation of slightly larger and less smooth plates [27].

\section{Design of the implant}

Overall, there are several advantages to the utilization of zero-profile devices. Zero-P device has plates that are integrated within the intervertebral disc site. This reduces impingement of prevertebral structures, such as the esophagus. The small titanium plate comes preassembled with an interbody spacer and provides a rigid locking interface for anchorage. The entire implant is contained within the disc space and eliminates the need for instrument protrusion 
outside the intervertebral space as in the case anterior cervical plate devices. Screws or anchorage blades are placed within the plate at a medial or lateral angle for fixation. A biomechanical study of low profile stand-alone cervical anterior cage device on 24 human cadaveric cervical spines, conducted by Scholz, et al., demonstrated similar mechanical stability to the traditional ACDF techniques using a standard anterior plate and cage designs [26].

ROI-C implant's characteristics are also similar to those of Zero-P device in many aspects (Table 1).

Being available in a variety of heights and footprints to match the patient's anatomy, ROI-C implants accommodate integrated, self-guided, self-locking plating designed to provide stability without a need for additional instrumentation protruding anterior of the vertebral bodies. The self-guided, curved plates are delivered in the plane of the disc through a direct anterior approach so that the surgery can be achieved with less exposure than may be required to implant a traditional cervical plate, or even contemporary stand-alone systems with screws that must be inserted at oblique and challenging angles.

Moreover, due to the implant design, there are significant reductions in operative time with fewer surgical steps as compared to procedures done with an anterior locking plate [30].

The findings of the current study suggest that in comparison to the anterior plate, utilization of the zero-profile device (regardless of the type) is associated with a reduced risk of persistent dysphagia while resulting in a comparable and favorable clinical outcome.

In addition, prevertebral soft tissue swelling is a common observation after ACDF. The severity of the prevertebral soft tissue edema, however, may in part be impacted by the type of instrumentation. In the present study, patients undergoing ACDF with a zero-profile device developed significantly less prevertebral soft tissue swelling as compared to those with an anterior plate. This trend was observed both at short-term $(<3$ months $)$ and long-term $(>3$ months) follow-up.

\section{Study limitations}

Several limitations exist in the design of the current study. We conducted a retrospective study of 104 patients comparing the clinical and radiographic outcome of the zero-profile device with the standard anterior plating. Patients were not randomized into different groups; therefore, a potential for selection bias exists. The retrospective nature of the study and the relatively low number of cases limits the statistical power of the study and necessitates interpretation of the results with precaution.

Nevertheless, statistical tests were performed to assess whether there were statistically significant differences between the two groups in the demographic and/or perioperative characteristics in which there were none except for a slight difference in the average age. The other limitation of the study was the lack of the preoperative soft tissue thickness measurement. As a result, the soft tissue thickness had been measured and compared between the two groups at the postoperative and the latest follow-up time points.

To attribute postoperative dysphagia in ACDF to the anterior plating system, double-blinded randomized controlled studies are needed.

\section{Conclusions}

Zero-profile devices are associated with similar clinical and functional outcomes as 
conventional constructs with anterior plates; nonetheless, the prevertebral soft tissue thickness and persistent dysphagia rates are lower with zero-profile implants. Further studies are required to delineate the pathophysiological mechanisms underlying dysphagia following ACDF.

\section{Additional Information \\ Disclosures}

Human subjects: Consent was obtained by all participants in this study. Neurological Surgery Patient Registry issued approval N/A. Animal subjects: All authors have confirmed that this study did not involve animal subjects or tissue. Conflicts of interest: In compliance with the ICMJE uniform disclosure form, all authors declare the following: Payment/services info: All authors have declared that no financial support was received from any organization for the submitted work. Financial relationships: All authors have declared that they have no financial relationships at present or within the previous three years with any organizations that might have an interest in the submitted work. Other relationships: All authors have declared that there are no other relationships or activities that could appear to have influenced the submitted work.

\section{Acknowledgements}

We want to thank AOSpine and Nuvasive for fellowship support. Thanks also to the Carol and Grace Hansen Spinal Research Fund.

\section{References}

1. Cherry C: Anterior cervical discectomy and fusion for cervical disc disease . AORN J. 2002, 76:998-1004. 10.1016/S0001-2092(06)61001-6

2. Cloward RB: The anterior approach for removal of ruptured cervical disks . J Neurosurg. 1958, 15:602-17. 10.3171/jns.1958.15.6.0602

3. Smith GW, Robinson RA: The treatment of certain cervical-spine disorders by anterior removal of the intervertebral disc and interbody fusion. J Bone Joint Surg Am. 1958, 40A:60724.

4. Cagli S, Isik HS, Zileli M: Cervical screw missing secondary to delayed esophageal fistula: case report. Turk Neurosurg. 2009, 19:437-40.

5. Gazzeri R, Tamorri M, Faiola A, Gazzeri G: Delayed migration of a screw into the gastrointestinal tract after anterior cervical spine plating. Spine (Phila Pa 1976). 2008, 33:E268-71. 10.1097/BRS.0b013e31816b8831

6. Pompili A, Canitano S, Caroli F, Caterino M, Crecco M, Raus L, Occhipinti E: Asymptomatic esophageal perforation caused by late screw migration after anterior cervical plating: report of a case and review of relevant literature. Spine (Phila Pa 1976). 2002, 27:E499-502.

10.1097/00007632-200212010-00016

7. Connolly PJ, Esses SI, Kostuik JP: Anterior cervical fusion: outcome analysis of patients fused with and without anterior cervical plates. J Spinal Disord. 1996, 9:202-6.

8. Song KJ, Taghavi CE, Lee KB, Song JH, Eun JP: The efficacy of plate construct augmentation versus cage alone in anterior cervical fusion. Spine (Phila Pa 1976). 2009, 34:2886-92. 10.1097/BRS.0b013e3181b64f2c

9. Böhler J, Gaudernak T: Anterior plate stabilization for fracture-dislocations of the lower cervical spine. J Trauma. 1980, 20:203-5.

10. Fraser JF, Härtl R: Anterior approaches to fusion of the cervical spine: a metaanalysis of fusion rates. J Neurosurg Spine. 2007, 6:298-303. 10.3171/spi.2007.6.4.2

11. Baron EM, Soliman AM, Gaughan JP, Simpson L, Young WF: Dysphagia, hoarseness, and unilateral true vocal fold motion impairment following anterior cervical diskectomy and fusion. Ann Otol Rhinol Laryngol. 2003, 112:921-26. 10.1177/000348940311201102

12. Bazaz R, Lee MJ, Yoo JU: Incidence of dysphagia after anterior cervical spine surgery: a prospective study. Spine (Phila Pa 1976). 2002, 27:2453-58. 10.1097/00007632-200211150- 
00007

13. Fujibayashi S, Shikata J, Kamiya N, Tanaka C: Missing anterior cervical plate and screws: a case report. Spine (Phila Pa 1976). 2000, 25:2258-61. 10.1097/00007632-200009010-00018

14. Hofstetter CP, Kesavabhotla K, Boockvar JA: Zero-profile anchored spacer reduces rate of dysphagia compared to ACDF with anterior plating. J Spinal Disord Tech. 2015, 28:E284-90.

15. Tortolani PJ, Cunningham BW, Vigna F, Hu N, Zorn CM, McAfee PC: A comparison of retraction pressure during anterior cervical plate surgery and cervical disc replacement: a cadaveric study. J Spinal Disord Tech. 2006, 19:312-17. 10.1097/01.bsd.0000210117.01897.ca

16. Frempong-Boadu A, Houten JK, Osborn B, Opulencia J, Kells L, Guida DD, Le Roux PD: Swallowing and speech dysfunction in patients undergoing anterior cervical discectomy and fusion: a prospective, objective preoperative and postoperative assessment. J Spinal Disord Tech. 2002, 15:362-68. 10.1097/00024720-200210000-00004

17. Fountas KN, Kapsalaki EZ, Nikolakakos LG, Smisson HF, Johnston KW, Grigorian AA, Lee GP, Robinson JS Jr: Anterior cervical discectomy and fusion associated complications . Spine (Phila Pa 1976). 2007, 32:2310-17. 10.1097/BRS.0b013e318154c57e

18. Heese O, Schröder F, Westphal M, Papavero L: Intraoperative measurement of pharynx/esophagus retraction during anterior cervical surgery. Part I: pressure. Eur Spine J. 2006, 15:1833-37. 10.1007/s00586-006-0069-0

19. Miao J, Shen Y, Kuang Y, Yang L, Wang X, Chen Y, Chen D: Early follow-up outcomes of a new zero-profile implant used in anterior cervical discectomy and fusion. J Spinal Disord Tech. 2013, 26:E193-E197. 10.1097/BSD.0b013e31827a2812

20. Azab W, Abdel-Razek M, Ali A, Abdelrahman A, Salaheldin W, Nasim K, Attia H, Soliman D: Outcome evaluation of a zero-profile implant for anterior cervical diskectomy with fusion . Turk Neurosurg. 2012, 22:611-17. 10.5137/1019-5149.JTN.5646-11.2

21. François JM, Castagnera L, Carrat X, Siméon F, Guatterie M, Devars F, Traissac L, Sénégas J: A prospective study of ENT complication following surgery of the cervical spine by the anterior approach (preliminary results). (Article in French). Rev Laryngol Otol Rhinol (Bord). 1998, 119:95-100.

22. Nurick S: The pathogenesis of the spinal cord disorder associated with cervical spondylosis . Brain. 1972, 95:87-100. 10.1093/brain/95.1.87

23. Benzel EC, Lancon J, Kesterson L, Hadden T: Cervical laminectomy and dentate ligament section for cervical spondylotic myelopathy. J Spinal Disord. 1991, 4:286-95.

24. Yonenobu K, Okada K, Fuji T, Fujiwara K, Yamashita K, Ono K: Causes of neurologic deterioration following surgical treatment of cervical myelopathy. Spine (Phila Pa 1976). 1986, 11:818-23.

25. Riley LH 3rd, Skolasky RL, Albert TJ, Vaccaro AR, Heller JG: Dysphagia after anterior cervical decompression and fusion: prevalence and risk factors from a longitudinal cohort study. Spine (Phila Pa 1976). 2005, 30:2564-69. 10.1097/01.brs.0000186317.86379.02

26. Scholz M, Reyes PM, Schleicher P, Sawa AG, Baek S, Kandziora F, Marciano FF, Crawford NR: A new stand-alone cervical anterior interbody fusion device: biomechanical comparison with established anterior cervical fixation devices. Spine (Phila Pa 1976). 2009, 34:156-60. 10.1097/BRS.0b013e31818ff9c4

27. Lee MJ, Bazaz R, Furey CG, Yoo J: Influence of anterior cervical plate design on Dysphagia: a 2year prospective longitudinal follow-up study. J Spinal Disord Tech. 2005, 18:406-9. 10.1097/01.bsd.0000177211.44960.71

28. Fountas KN, Kapsalaki EZ, Machinis T, Robinson JS: Extrusion of a screw into the gastrointestinal tract after anterior cervical spine plating. J Spinal Disord Tech. 2006, 19:199203. 10.1097/01.bsd.0000164164.11277.49

29. Mobbs RJ, Rao P, Chandran NK: Anterior cervical discectomy and fusion: analysis of surgical outcome with and without plating. J Clin Neurosci. 2007, 14:639-42.

10.1016/j.jocn.2006.04.003

30. Clavenna AL, Beutler WJ, Gudipally M, Moldavsky M, Khalil S: The biomechanical stability of a novel spacer with integrated plate in contiguous two-level and three-level ACDF models: an in vitro cadaveric study.. Spine J. 2012, 12:157-163. 10.1016/j.spinee.2012.01.011 